\title{
Glucose and lipid profile of obese dogs fed with different starchy sources
}

\author{
Perfil glicêmico e lipídico de cães obesos alimentados com diferentes fontes amiláceas
}

\author{
Mariana Lorenção Feitosa ${ }^{\mathrm{I}}$ Surama Freitas Zanini $^{\mathrm{I}^{*}}$ Dyeime Ribeiro de Sousa ${ }^{\mathrm{I}}$ \\ Elizabeth FantuzziII Thais Consuelo Loyola Carraro ${ }^{\text {III }}$ Camila Alves Pinto

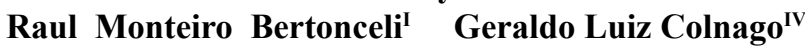

\section{ABSTRACT}

Among the health disorders caused by obesity in dogs stand out hyperglycemia and hyperlipidemia. Glycemic responses are directly related to the amount and type of starch. Thus, this study aimed to evaluate the effect of different sources of starch on glycemic and lipid levels in obese dogs. These dogs were distributed in a completely randomized design in a factorial $3 \times 2 \times 2$ (three sources starchy - corn (60\%), sorghum (60\%) and corn: sorghum (30:30\%), two breeds - Beagle and Dachshund and males and females. After 28 days of experiment, dogs fed with corn had higher amounts of glucose $\left(93.79 \mathrm{~A} \mathrm{mg} d L^{-1}\right)(P<0.05)$ compared with diets containing sorghum (88.00Bmg $\left.d L^{-1}\right)$ and corn: sorghum (88.75B mg dL $\left.L^{-1}\right)(P>0.05)$. Thus, dogs that consumed corn had a higher glycemic peak in a shorter time compared with dogs that ingested sorghum. Furthermore, the dogs fed with diet containing sorghum showed lower levels of fructosamine that dogs that ingested corn diet $(P<0.05)$ demonstrating that the diet containing sorghum maintained blood glucose over a longer time period that reduces the fluctuation of glucose in dogs. At 56 and 112 days of the experiment, a positive correlation between glucose levels and body weight $(P<0.05)$ was also observed. At 28, 56, 84 and 112 days, Beagle dogs showed higher serum concentrations of total cholesterol compared with Dachshund dogs $(P<0.05)$. It was concluded that the starchy source and breed can interfere with metabolic rates of obese dogs.

Key words: blood glucose, lipid profile, obesity, canine.

RESUMO

Dentre os transtornos de saúde causados pela obesidade em cães, destacam-se a hiperglicemia e a hiperlipidemia. As respostas glicêmicas estão diretamente relacionadas com a quantidade e o tipo de amido consumido. Objetivou-se avaliar o efeito de diferentes fontes de amido sobre os indices glicêmico e lipídico de cães obesos. Os animais foram distribuídos em um delineamento inteiramente casualizado em arranjo fatorial $3 \times 2 \times 2$ (três fontes amiláceas - milho (60\%), sorgo (60\%) e milho:sorgo (30:30\%), duas raças - Beagle e Dachshund-e dois sexos. Aos 28 dias de experimento, os cães alimentados com milho apresentaram maiores valores de glicose $\left(93,79 \mathrm{Amg}^{\mathrm{a}} \mathrm{L}^{-1}\right)(P<0,05)$, comparados com as dietas contendo sorgo $\left(88,00 B m g ~ d L^{-1}\right)$ e sorgo:milho $\left(88,75 \mathrm{Bmg} d L^{-1}\right)$, que não diferiram significativamente entre si $(P>0,05)$. Assim, os animais que ingeriram milho apresentaram um maior pico glicêmico em um menor tempo, quando comparado com os cães que ingeriram apenas sorgo. Além disso, os animais que ingeriram as dietas com sorgo apresentaram menores niveis de frutosamina do que os cães que ingeriram dieta com milho $(P<0,05)$, demonstrando que a dieta com sorgo proporcionou manutenção da glicemia por um periodo de tempo maior, reduzindo as flutuações de glicose nos cães. Aos 56 e 112 dias de experimento, foi observada correlação positiva entre os níveis glicêmicos e o peso corporal $(P<0,05)$. Aos 28, 56, 84 e 112 dias, os cães da raça Beagle apresentaram maior concentração sérica de colesterol total e de triglicerídeos que cães Dachshund $(P<0,05)$. Concluise que a fonte amilácea e a raça podem interferir nos indices metabólicos de cães obesos.

Palavras-chave: glicemia, lipidograma, obesidade, canino.

\section{INTRODUCTION}

The incidence of obesity in dogs is about $20-40 \%$ of the canine population (GOSSELLIN et al., 2007). Genetic, metabolic and endocrine factors determine its multiple etiologies (LEWIS et al.,

\footnotetext{
'Programa de Pós-graduação em Ciências Veterinárias, Departamento de Medicina veterinária, Universidade Federal do Espírito Santo (UFES), 29500-000, Alegre, ES, Brasil. E-mail: smzanini@yahoo.com.br. *Corresponding author.

IIDepartamento de Produção Vegetal, Universidade Federal do Espírito Santo (UFES), Alegre, ES, Brasil.

IIICurso de graduação, Departamento de Medicina Veterinária, Universidade Federal do Espírito Santo (UFES), Alegre, ES, Brasil.

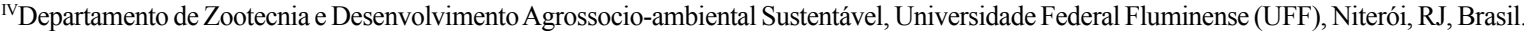
Received 09.21.15 Approved 06.03.16 Returned by the author 10.10.16 CR-2015-1327.R2
} 
1994). According to EDNEY and SMITH (1986) some breeds are predisposed to obesity.

Glucose is one nutrient which regulates the animal voluntary intake. Foods which have gradual release of glucose are more suitable for animal's health preventing obesity and physiological hyperinsulinemia (BORGES et al., 2003). Among the metabolic disorders related to obesity in dogs include hyperglycemia and the hyperlipidaemia (BURKHOLDER \& TOLL, 2000).

Studies in healthy adult dogs verified that the starch is the main compound responsible for the effect on the glycemic and insulinemic parameters (NGUYEN et al., 1998; CARCIOFI et al., 2008). Thus, the amount and type of starch consumed interfere with the glucose and insulin responses. Glucose can bind with amines groups of albumin and other blood proteins and lead to stable compounds called frutosamine.

Frutosamine is a glycated serum protein, resulting from non-enzymatic binding, irreversible and insulin-independent between glucose and circulating proteins. This glycation is dependent on blood sugar levels and protein, especially albumin. Assessment of concentration of frutosamine is important since high levels of blood glucose lead to increased glycation of proteins, as occurs in diabetic rats (BENNETT, 2002), since it disregards the momentary variation of the blood glucose because it reflects variations of blood glucose in the past two to three weeks (REUSCH et al., 1993).

In addition to hyperglycemia, obese dogs may also have hyperlipidemia, characterized by increasing concentration of lipids (JEUSETTE et al., 2005). Therefore this study aimed to evaluate the concentrations of glucose, fructosamine, cholesterol and triglycerides in obese dogs fed with diets with different starch sources.

\section{MATERIALS AND METHODS}

First of all, the dogs were given a complete physical examination, clinical and laboratory tests including complete blood count, renal and liver function, lipid profile, glucose profile, as well as ultrasound and abdominal computed tomography that attest to good health. Later prophylactic deworming and vaccination measures were used.

The study consisted of two phases. The first phase (pre-trial) was characterized by the induction of obesity through the ad libitum consumption of a maintenance diet, a commercial, nutritionally complete and balanced extruded dry- type diet. Approximately 60 days after the induction of obesity, the dogs reached a body condition score (BCS) equal or superior to seven. It was used the body condition score (BCS) described by LAFLAMME (1997) for the selection of dogs to experimental phase. Dogs remained on experimental phase for 112 days.

In the experimental phase, it was used 36 mature dogs, there were 18 Beagle breed, with an average of six (6) years +4 months of age and $14.47 \pm 2.18 \mathrm{~kg}$ of body weight and 18 Dachshund breed dogs in average of five (5) years +2 months of age, and $6.97 \pm 1.05 \mathrm{~kg}$ of body weight. Dogs were distributed in a completely randomized design in a factorial 3x2x2 (three sources starchy - corn (60\%), sorghum (60\%) and corn: sorghum (30:30\%), two breeds - Beagle and Dachshund and males and females, with six replications/diet, three males and three females of each breed.

The experimental diets were primarily composed of corn, soybean meal, chicken by-product meal, meat and bone meal and poultry fat as reported by FEITOSA et al. (2015). Experimental diets were isocaloric (3300kcal metabolizable energy $\mathrm{kg}^{-1}$ ) and isonitrogenous ( $22 \%$ crude protein) following the recommendations of the American Association of Feed Control Official (AAFCO, 2007). Food intake occurred in two daily meals. Daily amount of food for each animal was calculated using the estimated daily requirement of metabolizable energy for maintenance $\left(95 \mathrm{kcal}^{\mathrm{k}} \mathrm{-}^{-0.75}\right)$. This amount was adjusted every two weeks, after dogs' weighing.

Every 28 days, individual blood samples were collected by jugular puncture. For this, dogs were subjected to fasting for a period of 12 hours. Blood was deposited in vacuum tubes (Vacutainer ${ }^{\mathbb{R}}$ ) with and without anticoagulant. Then the samples were centrifuged for 10 minutes at 2,000xg to obtain the serum. After this process, the serum was separated in $1.0 \mathrm{ml}$ polypropylene microtubes (Eppendorf) and stored under refrigeration $\left(4\right.$ to $8^{\circ} \mathrm{C}$ ) for further analysis. Results of biochemical parameters were obtained on the automated analyzer (Biosystens A5) using standardized commercial reagents $\left(\right.$ Labtest $^{\mathbb{B}}$ and Biosystens ${ }^{\circledR}$ ), following the methods recommended by manufacturers. Serum concentrations of glucose, fructosamine, cholesterol and triglycerides were assayed in duplicate.

Results of the evaluated parameters were submitted to analysis of variance (ANOVA) and Pearson correlation, using the computational package (UFV, 1997), considering the significance level of $5 \%(\mathrm{P}<0.05)$. 


\section{RESULTS AND DISCUSSION}

In our study, values of glucose, cholesterol, triglyceride and fructosamine were observed (Tables 1-3). It was used the reference range for adult dogs, from 112 to $328 \mathrm{mg} \mathrm{dL}^{-1}$ for cholesterol, 20 to $150 \mathrm{mg} \mathrm{dL}^{-1}$ for triglycerides, 65 to $118 \mathrm{mg} \mathrm{dL}^{-1}$ for glucose and 1.7 to $3.4 \mathrm{mmol} \mathrm{L}^{-1}$ for fructosamine in healthy dogs (KANEKO et al., 1997).

At 28, 56, 84 and 112-day experiment, it was verified significant difference in blood glucose levels and cholesterol levels between males and females $(\mathrm{P}<0.05)$. On average, males had higher glucose levels $\left(95.80 \pm 8.93 \mathrm{mg} \mathrm{dL}^{-1} \mathrm{~A}\right)$ than females $(87.88 \pm 8.18 \mathrm{mg}$ $\left.\mathrm{dL}^{-1} \mathrm{~B}\right)(\mathrm{P}<0.05)$. Conversely, on average, females have a higher concentration of cholesterol $(196.76 \pm 1.2 \mathrm{~A})$ than males $(178.54 \pm 2.42 \mathrm{~B})(\mathrm{P}<0.05)$. FONSECA-ALANIZ et al. (2006) and FEITOSA et al. (2015) reported there are gender differences in energy efficiency.

At 28-day experiment, it was also verified significant effect of diet on blood glucose levels $(\mathrm{P}<0.05)$. Dogs fed corn had higher blood glucose

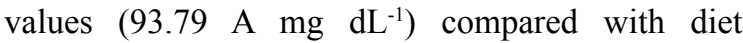
containing sorghum (88.00 $\left.\mathrm{B} \mathrm{mg} \mathrm{dL}^{-1}\right)$ and sorghum: corn $\left(88.75 \mathrm{~B} \mathrm{mg} \mathrm{dL}^{-1}\right)(\mathrm{P}>0.05)$. Our results are in agreement with those observed by BOUCHARD \& SUNVOLD (1999) that verified higher glucose concentrations in dogs fed with extruded diets containing rice, wheat, corn and lower levels for sorghum and barley. For EUKANUBA (2003), the slow digestion of carbohydrates of sorghum and barley sources result in moderate levels of postprandial glucose. CARCIOFI et al. (2008) also reported that blood glucose peaks were achieved faster in diets with corn, broken rice and cassava flour compared to those of sorghum which were slower.

At 56 and 112-day experiment, there was an interaction effect between breed and diet on blood glucose $(\mathrm{P}<0.05$; Table 2$)$, total cholesterol concentration $(\mathrm{P}<0.05$; Table 2$)$ and triglycerides $(\mathrm{P}<0.05$; Table 2). Among the Dachshund-group, those fed with sorghum had the lowest glycemic level (Table 2). Therefore, dogs fed with corn had increased glycemic peak in a shorter time as compared with dogs that were fed only with sorghum. These findings corroborate those reported by CARCIOFI et al. (2008) that glucose and insulin peaks occurred earlier for the diet with rice, manioc flour and corn compared to diets with sorghum.

Our results also showed that among dogs fed with sorghum, the Dachshund-group had lower serum total cholesterol and triglycerides (Table 2) compared with Beagle-group $(\mathrm{P}<0.05)$. For dogs fed with corn diet, there was no difference on blood glucose, total cholesterol and triglycerides levels between the dogs breeds $(\mathrm{P}>0.05)$.

Additionally, it was also observed that Beagle-group showed lowest total cholesterol concentration and triglycerides levels when fed with corn but the opposite was observed when fed sorghum diet. It was suppose that these findings are related to body mass index and energy metabolism. FEITOSA et al. (2015) reported that Beagle dogs showed a high body mass index (BMI) compared to the Daschund-group. Body mass index increases due to excessive weight. Excessive accumulation of body fat is the condition that characterizes obesity (MULLER et al., 2008).

Furthermore, APPLETON et al. (2001) observed that obesity causes reversible insulin resistance, altering tissue glucose tolerance, even though there is hyperglycemia, which can be reversed when obesity is cured. Therefore, in obesity, it can occur inability to utilization of glucose by muscles, and under these conditions is deployed a greater amount of fat for energy, increasing the circulating lipids (SILVERTHORN, 2010).

Thus, there is a significant increase in cholesterol in obese dogs, which can result in a higher concentration of these metabolites in circulating lipoprotein (CHIKAMUNE et al., 1995). As well as, middle-aged and older dogs are more prone to obesity and the most prevalent age range is between 5 to 10

Table 1 - Mean values of serum fructosamine concentrations $(\mu \mathrm{mol} / \mathrm{L})$ and respective standard deviation in dogs fed with experimental diets during 112 days.

\begin{tabular}{|c|c|c|c|c|c|}
\hline Diets & 0 day $^{\mathrm{NS}}$ & 28 days $^{\mathrm{NS}}$ & 56 days & 84 days & 112 days \\
\hline Corn & $1.999 \pm 0.32$ & $1.906 \pm 0.23$ & $1.893 \pm 0.17 \mathrm{~A}$ & $1.936 \pm 0.23 \mathrm{~A}$ & $1.943 \pm 0.23 \mathrm{~A}$ \\
\hline Sorghum & $1.958 \pm 0.31$ & $1.878 \pm 0.24$ & $1.790 \pm 0.16 \mathrm{~B}$ & $1.664 \pm 0.14 \mathrm{~B}$ & $1.727 \pm 0.18 \mathrm{~B}$ \\
\hline Corn:sorghum & $1.972 \pm 0.32$ & $1.899 \pm 0.23$ & $1.866 \pm 0.13 \mathrm{~A}$ & $1.837 \pm 0.19 \mathrm{~A}$ & $1.864 \pm 0.15 \mathrm{~A}$ \\
\hline
\end{tabular}

${ }^{\mathrm{A}, \mathrm{B}}$ Different capital letters in the same column differ by SNK test $(\mathrm{P}<0.05)$.

NS: Not significant $(\mathrm{P}>0.05)$. 
Table 2 - Mean values of serum total cholesterol (mg dL-1), triglycerides (mg dL-1) and serum glucose concentrations (mg dL-1) in dogs of Beagle and Dachshund breeds fed with experimental diets.

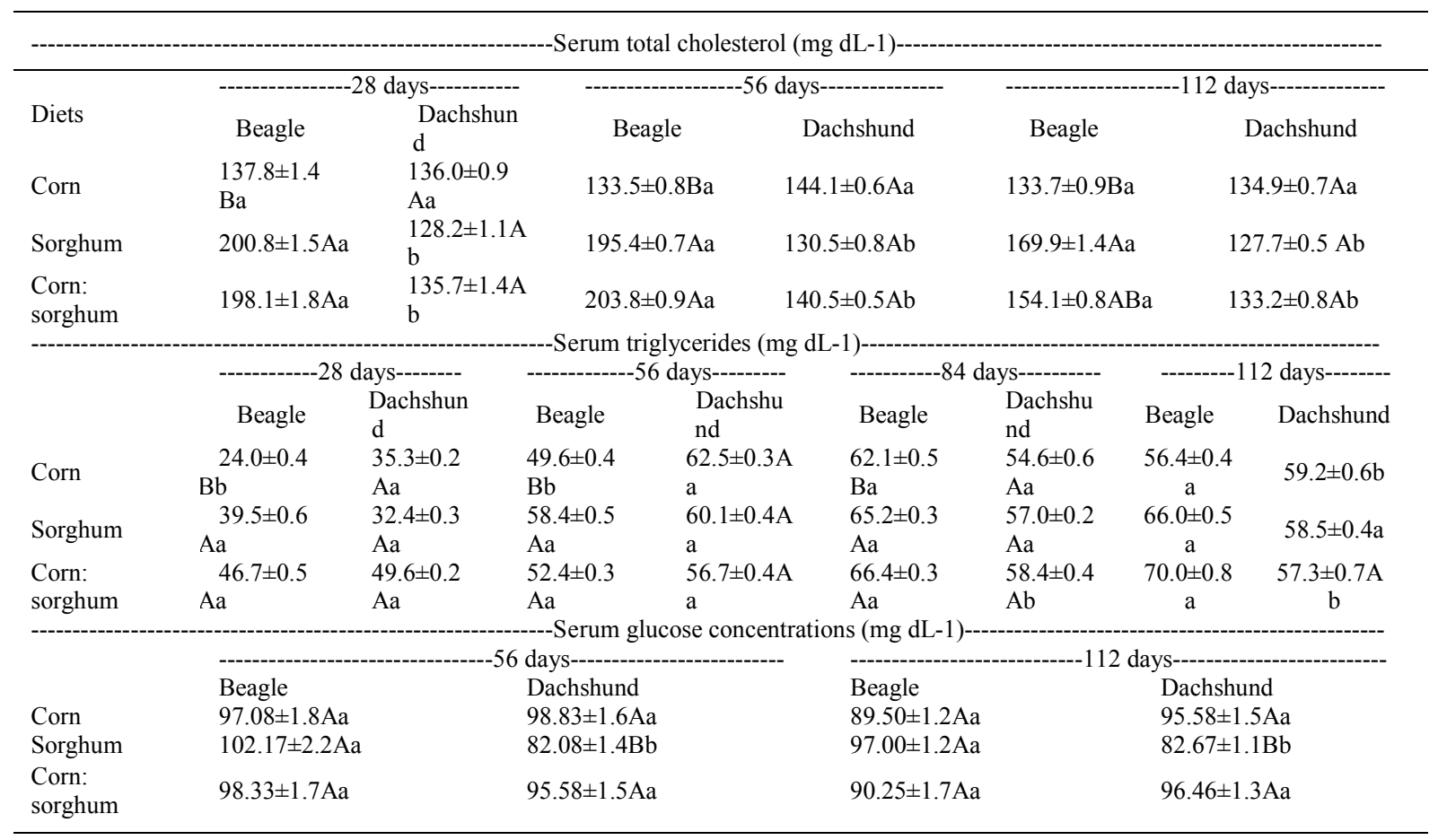

${ }^{\mathrm{A}, \mathrm{B}}$ Different capital letters in the same column differ by SNK test $(\mathrm{P}<0.05)$.

${ }^{\mathrm{A}, \mathrm{B}}$ Different small letters in the same row differ by SNK test $(\mathrm{P}<0.05)$.

years (LEWIS et al., 1994; LAFLAMME, 2005; BRUNETTO et al., 2011).

It is known that the mobilization of body fat results in the elevation of free fatty acids (FFA) in circulation which inhibits the metabolism of glucose via fatty acid cycle/glucose. The increase of FFA leads to beta-oxidation and consequently increase the production of acetyl-CoA. This leads to the inhibition of pyruvate dehydrogenase and consequently the oxidation of pyruvate. At the same time, the increase of ATP and citrate leads to inhibition of phosphofructokinase and glycolysis resulting in glucose 6-phosphate accumulation. This in turn leads to the inhibition of hexokinase activity, with reduced uptake and phosphorylation of glucose, and consequent increase in blood glucose (LEHNINGER et al., 2003). This event was demonstrated by the positive correlation between the level of glucose and total cholesterol at 56 and 112 days of the experiment $(\mathrm{P}<0.05)$. At $28,56,84$ and 112 days of the experiment, it was reported breed effect on total cholesterol $(\mathrm{P}<0.05)$. Beagles dogs had higher total

Table 3 - Mean values of serum fructosamine $\left(\mu \mathrm{mol} \mathrm{L}^{-1}\right)$ and total cholesterol $\left(\mathrm{mg} \mathrm{dL}^{-1}\right)$ in dogs of Beagle and Dachshund breeds fed with experimental diets.

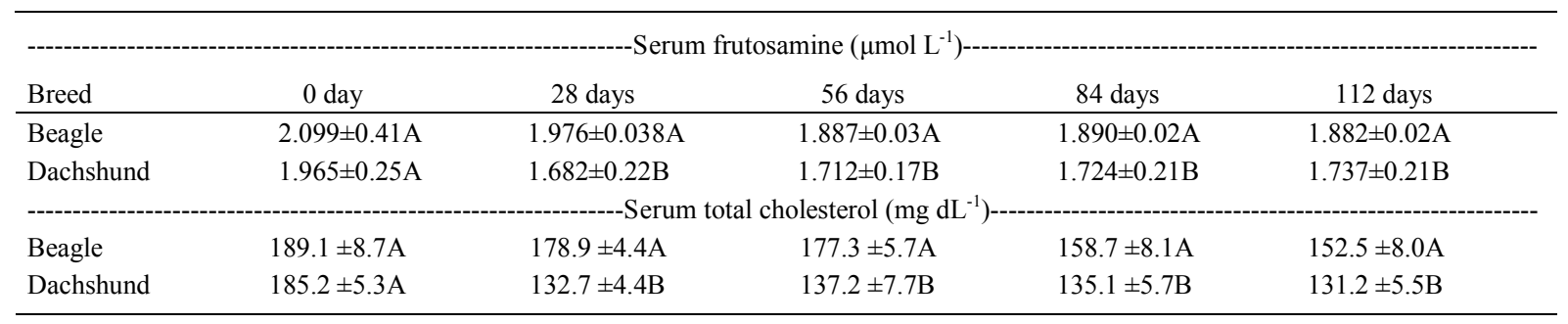

${ }^{\mathrm{A}, \mathrm{B}}$ Different capital letters in the same column differ by SNK test $(\mathrm{P}<0.05)$. 
serum cholesterol levels compared with Dachshundgroup $(\mathrm{P}<0.05)$ (Table 3$)$.

At 56 and 112 days of the experiment, it was also observed a positive correlation between glucose levels and body weight $(\mathrm{P}<0.05)(\mathrm{r}=0.82$ and 0.87 , respectively). Thus, dogs with lower glycemic indexes had the lowest body weight. According to BELL et al. (1987), the association between blood glucose and insulin can induce a food intake because the higher concentration of plasma glucose, increased circulating insulin, which carries a secondary negative feedback by reducing blood glucose levels that favors a higher food intake and higher body weight.

The fructosamine corresponds to the stable form of glycosylated proteins which undergo post-translational modification with the addition of glucose to protein structure. At the moment, there are few studies that show the fructosamine concentrations in dogs fed with different starch sources. At the beginning of the experiment, as well as at 28-day experiment, it was verified the serum fructosamine values did not differ between the experimental diets $(\mathrm{P}>0.05)$. However, at 56, 84 and 112-days experiment, there was the effect of diet on concentrations of fructosamine $(\mathrm{P}<0.05)$. Dogs fed with sorghum diet showed lower levels of fructosamine than group fed diet with corn (Table 1). Insulin and glycemic responses reflect the speed at which the starch is digested and absorbed as glucose. Among the factors that influence starch digestion include the structure of your beads, degree of binding, protein encapsulation and its chemical composition, especially the proportions of amylose and amylopectin. Generally, starches with high relative amylose amylopectin are more rigid and resistant to breakage than starches with lower ratio values (ROONEY \& PFLUGFELDER, 1986). These differences allow the classification of starches as rapid digestion of starch, slowly digestible starch and resistant starch (ENGLYST et al., 1993).

Subsequently, CARCIOFI et al. (2008) reported that the diet with sorghum provides maintenance of blood glucose for a longer period of time reducing glucose fluctuations in dogs. Fructosamine is considered a major tool in longterm control of blood glucose differentiating hyperglycemia that occurs in dogs stressed during the blood collection (FELDMAN \& NELSON, 2004).

There was a significant effect of breed on the fructosamine levels $(\mathrm{P}<0.05)$. At $28,56,84$ and 112-days experiment, the Beagle dogs showed a higher level of fructosamine compared with Dachshund-group $(\mathrm{P}<0.05)$. This effect is related to the glucose level.

\section{CONCLUSION}

It was concluded that the starchy source and breed can interfere in the metabolic rates of obese dogs.

\section{BIOETHICS AND BIOSSECURITY COMMITTEE APPROVAL}

The experimental procedures were approved by the Ethics and Animal welfare Health Sciences Center at the Universidade Federal de Espirito Santo, with number of 23068.741463 / 2009-92 and all the recommended ethical principles on the use of dogs in experiments were observed.

\section{ACKNOWLEDGMENTS}

The Conselho Nacional de Desenvolvimento Científico e Tecnológico (CNPq) for financial support to carry out this research.

\section{REFERENCES}

APPLETON, D.J. et al. Insulin sensitivity decreases with obesity, and lean cats with low insulin sensitivity are at great risk of glucose intolerance with weight gain. Journal of Feline Medicine and Surgery, v.3, p.211-228, 2001. Available from: $<\mathrm{http}: / / \mathrm{jfm}$. sagepub.com/content/3/4/211.long $>$. Accessed: Sept. 24, 2015. doi: $10.1053 / \mathrm{jmms} .2001 .0138$.

ASSOCIATION OF AMERICAN FEED CONTROL OFFICIALS - AAFCO. Official publication 2007. Available from: <http://www. aafco.org/Publications/PublicationListing.aspx $>$. Accessed: 13 dez. 2014.

BELL, A.W. et al. Regulation of nutrient partitioning and metabolism during pré-and postnal growth. Journal Animal Science, v.65, n.1, p.186, 1987.

BENNETT, N. Monitoring techniques for diabetes mellitus in dogs and cats. Clinical Techniques in Small Animal Practive, v.17, n.2, p.65-69, 2002. Available from: <http://www.sciencedirect. com/science/article/pii/S109628670280038X >. Accessed: Sept. 24, 2015. doi: 10.1053/svms.2002.33044.

BORGES, F.M.O. et al. Recent advances in nutrition of dogs and cats. In: SYMPOSIUM ON PETS NUTRITION, 2003, Campinas, SP. Anais... Campinas: CBNA, 2003. p.21-60.

BOUCHARD, G.F.; SUNVOLD, G.D. Improving canine glycemic response to a meal with dietary starch. In: THE NORTH AMERICAN VETERINARY CONFERENCE, 1999, ORLANDO.

Proceedings... Recent advances in clinical management of diabetes mellitus. Orlando: The Lams, 1999. p.16-19.

BRUNETTO, M.A. et al. Correspondence between obesity and hyperlipidemia in dogs. Ciência Rural, v.41, p.266-271, 2011. Available from: <http://dx.doi.org/10.1590/S010384782011005000004>. Accessed: Sept. 24, 2015. doi: 10.1590/ S0103-84782011005000004.

BURKHOLDER, W.J.; TOLL, P.W. Obesity. In: HAND, M.S. et al. Small animal clinical nutrition. 4.ed. Topeka: Mark Morris Institute, 2000. p. 401-430, 2000. 
CARCIOFI, A.C. et al. Effects of six carbohydrate sources on dog diet digestibility and post-prandial glucose and insulin response. Journal of American Physiology and Animal Nutrition, v.92, p.326-336, 2008. Available from: < http://onlinelibrary.wiley.com/ doi/10.1111/j.1439-0396.2007.00794.x/abstract>. Accessed: Sept. 24, 2015. doi: 10.1111/j.1439-0396.2007.00794.x.

CHIKAMUNE, T. et al. Serum lipid and lipoprotein concentrations in obese dogs. Journal of Veterinary Medical Science, v.57, n.4, p.595-598, 1995. Available from: <http://www.ncbi.nlm.nih.gov/ pubmed/8519883>. Accessed: Sept. 24, 2015.

EDNEY, A.T.; SMITH, P.M. Study of obesity in dogs visiting veterinary practices in the United Kingdom. Veterinary Record, v.118, p.391-396, 1986.

ENGLYST, H.N. et al. Resistant starch: measurement in foods and physiological role in man. In: MEUSER, D.J.; SEIBEL, W. Plant polymeric carbohydrates. Cambridge: Royal Society of Chemistry, 1993. p.137-146.

EUKANUBA. Information, 2003. Available from: <http:www. goldenretrivers.co.nz/eukanuba_info.htm $>$. Online. Accessed: Nov. 23, 2009.

FEITOSA, M.L. et al. Starchy sources as a feeding strategy to control obesity in dogs. Ciência Rural, v.45, n.3, p.546-551, 2015. Available from: <http://www.scielo.br/pdf/cr/v45n3/1678-4596cr-45-03-00546.pdf>. Accessed: Sept. 24, 2015.

FONSECA-ALANIZ M.H. et al. The adipose tissue as a regulatory center of the metabolism. Arquivo Brasileiro de Endocrinologia Metabólica, v.50, n.2, p.216-229, 2006. Available from: <http:// dx.doi.org/10.1590/S0004-27302006000200008>. Accessed: Dec. 03, 2010. doi: 10.1590/S0004-27302006000200008.

GOSSELLIN, J. et al. Canine obesity - an overview. Journal Veterinary Pharmacology Therapy, v.30, p.1-10, 2007. Available from: <http://onlinelibrary.wiley.com/doi/10.1111/ j.1365-2885.2007.00863.x/abstract>. Accessed: Sept. 24, 2015. doi: $10.1111 / \mathrm{j} .1365-2885.2007 .00863$.x.

JEUSETTE, I. et al. Ad libitum feeding fllowing ovariectomy in female Beagle dogs: effect on maintenance energy requirement and on blood metabolites. Journal of Animal Physiology and Animal Nutrition, v.88, n.3-4, p.117-121, 2004. Available from: <http:// onlinelibrary.wiley.com/doi/10.1111/j.1439-0396.2003.00467.x/ abstract $>$. Accessed: Sept. 24, 2015. doi: 10.1111/j.14390396.2003.00467.x.
KANEKO, J. J. Clinical biochemisty of domestic animals. 5. ed, New York: Academis Press, 1997. 932p.

LAFLAMME, D.P. Development and validation of a body condition score system for dogs. Canine Practice, v.22, p.10-15, 1997.

LAFLAME, D. P. Nutrition for aging cats and dogs and the importance of body condition. Veterinary Clinics Small Animal Practice, v. 35, 713-742, 2005.

LEHNINGER, A. et al. Princípios de bioquímica. 3.ed. São Paulo: Sarvier, 2003. 975p.

LEWIS, L.D. et al. Obesity. In: LEWIS, L.D. et al. Small animal clinical nutrition III. Topeka, Kansas: Mark Morris Institute, 1994. p.1-39.

MULLER, D.C.M. et al. Adaptation of human body mass index for dogs. Ciência Rural, v.38, n.4, p.1038-1043. 2008. Available from: $<$ http://www.scielo.br/scielo.php?script=sci_ arttext\&pid=S010384782008000400020\&1ng=en\&nrm $=$ iso $>$. Accessed: Aug. 07, 2015. doi: 10.1590/S010384782008000400020 .

NGUYEN, P. et. al. Glycemic and insulinic responses after ingestion of comercial foods in healthy dogs: Influence of food composition. Journal of Nutrition, v.128, p.2654S-2658S, 1998. Available from: $<$ http://jn.nutrition.org/content/128/12/2654S.full. pdf + html $>$. Accessed: Sept. 24, 2015.

REUSCH, C.E. et al. Fructosamine: a new parameter for diagnosis and metabolic control in diabetic dogs and cats. Journal of Veterinary Internal Medicine, v.7, n.3, p.177182, 1993. Available from: <http://onlinelibrary.wiley.com/ doi/10.1111/j.1939-1676.1993.tb03183.x/pdf>. Accessed: Sept. 24, 2015. doi: 10.1111/j.1939-1676.1993.tb03183.x/pdf.

ROONEY, L.W.; PFLUGFELDER, R.L. Factors affecting starch digestibility with special emphasis on sorghum and corn. Journal Animal Science, v.63, p.1607-1623, 1986. Available from: <http://www.ncbi.nlm.nih.gov/pubmed/3539904>. Accessed: Sept. 24, 2015.

SILVERTHORN, D.U. Fisiologia Humana: uma abordagem integrada. 5.ed. Porto Alegre, Artmed, 2010, 992 p.

UFV (UNIVERSIDADE FEDERAL DE VIÇOSA). Manual de utilização do Programa SAEG. Viçosa, 1997. 150 p. 